\title{
Call Types of the Oriental Magpie Robin (Copsychus saularis) in Suburban Areas in Kota Samarahan, Sarawak
}

\author{
ZAHRAN MANSOR* \& DENCY FLENNY AUGUSTINE GAWIN
}

\author{
Faculty of Resource Science and Technology, Universiti Malaysia Sarawak, 94300 Kota Samarahan, Sarawak, \\ Malaysia \\ *Corresponding author: zahranmansor@yahoo.com \\ Received: 11 May $2020 \quad$ Accepted: 12 June $2020 \quad$ Published: 30 June 2020
}

\begin{abstract}
The Oriental Magpie Robin (Copsychus saularis) is among the popular passerines songbird in Borneo. A study on the vocalisation of this tropical species has been conducted at Universiti Malaysia Sarawak (UNIMAS) Campus and Tanjung Bundong village areas, Kota Samarahan, Sarawak starting from March 2015 until February 2017 to understand more on their call types. Call samples were recorded from 38 individuals of Magpie Robin (8 colour-ringed males, 6 colour-ringed females, 10 juveniles and 14 nestlings) during breeding seasons. A total of six call types were successfully identified which were territorial, threat, submissive, juvenile, distress and begging calls. Both territorial and threat calls are uttered in response to the presence of an intruder in the vicinity of nesting sites while begging call is crucial to the nestlings as it stimulates parental food provisioning activities. Distress call was uttered when in stress situations while juvenile calls were associated with learning process to vocalise. Territorial, threat and begging calls were substantially important during breeding season and the survival of Magpie Robins.
\end{abstract}

Keywords: Breeding season, call types, Oriental Magpie Robin

Copyright: This is an open access article distributed under the terms of the CC-BY-NC-SA (Creative Commons Attribution-Non Commercial-Share Alike 4.0 International License) which permits unrestricted use, distribution, and reproduction in any medium, for non-commercial purposes, provided the original work of the author(s) is properly cited.

\section{INTRODUCTION}

Birds use a variation of acoustic signals in their communication beside other signals such as morphological signals (Kumar, 2003), environmental signals (Carey \& Dawson, 1999) and visual signals (Vincze et al., 2015). Birds rely on acoustic signals to find mating partners, dissuade competitors or avoid predators (Bradbury \& Vehrencamp, 2011). Bird's vocalisation can be classified into call and song (Catchpole \& Slater, 2008). Both call and song can be distinguished according to their acoustical characteristics. Songs have longer duration, flexible structures and pattern while being uttered spontaneously mostly by males and mainly during breeding season (Bhattacharya et al., 2007; Catchpole \& Slater, 2008). In contrast to songs, calls often have simpler and shorter duration and less spontaneously uttered by both sexes throughout the year (Kumar \& Bhatt, 2001; Sethi et al., 2012). In most species, songs have been regarded as one of strategies used by males to attract mate and secure breeding territory, while calls serve a variety of practical, non-sexual functions like finding and recognising members of a flock, signaling about foods, alarms for predators and begging pleas (Catchpole \& Slater, 2008).

The Oriental Magpie Robin (Copsychus saularis) (Linnaeus, 1758) is a passerines species (Turdidae) of open habitats (Lekagul \& Round, 1991) that can be found in coastal regions, mangroves, forest edge and man-made habitats including gardens, plantations and cultivated areas (Wells, 2007; Mann, 2008). Morphologically, this sexually dimorphic species can be characterized by its possession of prominent black and white plumage colour, black bill, grey legs and black tail. Male has black upperparts and throat, while white for underparts and side of the tail. As for female, the black colour of male is replaced with grey colour (Ali \& Ripley, 2001). This bird species utters their calls throughout the year. Several call types were uttered outside breeding season which usually involve practical, non-sexual functions, while other call types have significant roles during 
breeding season (Kumar \& Bhatt, 2001).

This paper aims at investigating the use of acoustic communication specifically calls by the Oriental Magpie Robin in the western part of Sarawak. Based on the observations and sound recordings using a microphone, we described the contexts and behaviours of the birds when calling.

\section{MATERIALS AND METHODS}

\section{Study Sites and Sound Recordings}

This study was conducted in Universiti Malaysia Sarawak (UNIMAS) Campus and Tanjung Bundong village areas in Kota Samarahan, Sarawak from March 2015 until February 2017. The habitat in the campus areas can be described as being surrounded by secondary and mix peat swamp forests while along the roadside in the campus are planted with various ornamental trees (Voon et al., 2014).

All sounds were recorded by using a directional microphone (Sennheiser MKH 20 P48) and solidstate recorder (Marantz pro solid-state recorder PDM67). All calls were recorded in their daily home range. Most of the sound recordings were conducted in UNIMAS campus areas. Nestling vocalizations were progressively collected in the nest starting from the hatching day until they fledged. All call signals were collected from 8 colour-banded males, 6 colour-banded females, 10 juveniles and 14 nestlings during breeding season (mostly during incubation and nestling phases) as well as during ringing process.

\section{Sound Analysis}

All recordings were saved as WAV files, viewed and analysed by using Raven Pro: Interactive Sound Analysis Software (Version 1.4) [Computer software] Ithaca, NY: The Cornell Lab of Ornithology. All call spectrograms (graphic representation of sounds) were generated by the software with the following settings; Hamming window (733 points, $16.6 \mathrm{~ms}$ ), 16-bit resolution, frequency grid spacing of $43.1 \mathrm{~Hz}$ and DFT size of 1024 samples.

The acoustical features and characteristics of recorded sounds were defined by measuring the physical characteristics of the sound: 1) minimum frequency $(\mathrm{kHz})$ (the lowest frequency of a particular call), 2) maximum frequency $(\mathrm{kHz})$ (the highest frequency of a particular call), 3) range of frequency $(\mathrm{kHz})$ (a total of frequency between the lowest and highest frequency), 4) duration of a call (s) (total time taken by a particular call to occur) and 5) length of interval between call (s) (duration of time from the last element of a call to the first element in the subsequent call). Data were presented in mean $\pm \mathrm{SE}$.

The classification and identification of call types were made by visual inspection of the generated spectrograms. Calls were defined and sorted accordingly based on structures and shapes of elements with reference to behavioural responses of individuals (Byers, 1996; Kumar \& Bhatt, 2001). The total number and types of elements for each call were counted and defined respectively, while the physical characteristics of each call type were measured and recorded. All phonetic representations for every call type were defined and noted by listening back the audio samples. All vocal outputs were compared to a study done by Kumar and Bhatt (2001).

\section{RESULTS}

Throughout the study period, a total of six call types were successfully identified which are 1) territorial, 2) threat, 3) submissive, 4) distress, 5) juvenile and 6) begging calls (Figure 1).

Territorial call. - The territorial call is similar to a whistling sound, which can be heard as "swee. ... swee. ...". Both sexes were seen to utter this call throughout the year, but the rate of utterance was much higher during the breeding season. The inspection of spectrograms revealed that this type of call consisted of two types of elements (Figure 1). The element type I initiated at higher frequency and it ended at lower frequency, and it was vice versa for the element type II. On many occasions, the territorial calls were typically uttered in a stereotyped sequence of element type I call. On the other hand, the element type II was usually uttered alternately with the element type I, although this only happened occasionally. The element type I of territorial call has a minimum and maximum frequencies of $2.60 \pm 0.05 \mathrm{kHz}$ and $3.80 \pm 0.03$ $\mathrm{kHz}$, respectively, $1.21 \pm 0.05 \mathrm{kHz}$ of range of frequency, duration of $0.73 \pm 0.02 \mathrm{~s}$ with an interval of $3.65 \pm 0.38 \mathrm{~s}$ between calls and the rate of production was $18.43 \pm 1.48$ calls per minute (Table 1). The element type II of territorial call note 
has a minimum and maximum frequencies of 3.49 $\pm 0.04 \mathrm{kHz}$ and $4.71 \pm 0.09 \mathrm{kHz}$, respectively, 1.22 $\pm 0.06 \mathrm{kHz}$ of range of frequency, $0.72 \pm 0.02 \mathrm{~s}$ of duration with an interval between calls of $4.03 \pm$ $0.36 \mathrm{~s}$. The average rate of its utterance was 13.93 \pm 1.03 calls per minute (Table 1 ).

Threat call. - Magpie Robin's threat call is a simple type of call composed of a series of monosyllabic elements. The call is a harsh, shrill and can be heard as "charr. . . charr. ...". This broad band, low amplitude signal call has a minimum and maximum frequencies of $2.35 \pm 0.13$ $\mathrm{kHz}$ and $5.42 \pm 0.11 \mathrm{kHz}$, respectively. The range of frequency was found to be $3.08 \pm 0.13 \mathrm{kHz}$. The duration was $0.68 \pm 0.04 \mathrm{~s}$ with an interval between calls of $4.28 \pm 0.49 \mathrm{~s}$. The average rate of calls production was $15.90 \pm 1.22$ calls per minute (Table 1). In most cases, the threat call was uttered in a stereotyped sequence of elements. The birds also uttered the threat call alternately with the territorial call occasionally. However, the two alternating calls from an individual were uncertain and could not be predicted. The males and females uttered this call mostly during breeding season and sometimes during non-breeding season. Both sexes produced the agonistic call, once there were intruders (non-conspecifics and sometimes the observers) near their nest vicinity. Magpie Robins were also observed to utter the threat call while chasing non-conspecific invaders. The frequency and intensity of threating call would vary according to the situations as they encountered with. In most occasions, threat calls were produced as soon as humans approach their nest vicinity.

Submissive call. - The submissive calls were phonetically rendered as "cheo ... chee ... . chee .. . . chee ...". The minimum and maximum frequences of their submissive call were $2.13 \pm$ 0.05 and $5.62 \pm 0.12 \mathrm{kHz}$, respectively. The range of frequency was $3.49 \pm 0.13 \mathrm{kHz}$. The call duration was $0.91 \pm 0.09 \mathrm{~s}$ with an interval of 1.36 $\pm 0.23 \mathrm{~s}$ between calls. The average submissive call rate was $34.09 \pm 4.67$ calls per minute (Table 1 ). The inspection of spectrogram revealed that submissive call was made up of two types of elements, type A and type B (Figure 1). In most cases, the element type A was uttered once and followed by several of repetitions of element type B (one to five times) in a single call. Sometimes, the element type A was successfully uttered twice in one call, followed by a few of repetitions of element type B.

Distress call. - The distress call was uttered when both sexes are under pressure. The rate of distress call varied according to the situations they were in. The birds uttered the call rapidly when being held firmly and the intensity reduced once the pressure had loosened. This call was phonetically rendered as "tseeerrr . . . . tseeerrr . . ..". The distress call has a minimum, maximum, range of frequencies of $1.05 \pm 0.06,7.14 \pm 0.06$ and $6.09 \pm$ $0.08 \mathrm{kHz}$, respectively. The call duration was 0.44 $\pm 0.02 \mathrm{~s}$ with an interval of $6.05 \pm 0.82 \mathrm{~s}$ between calls. The average rate of distress call was $21.18 \pm$ 3.27 calls per minute (Table 1). Similar to the threat calls, the distress call has an abrupt onset and termination. However, the frequency range was wider than that of the threat calls.

Juvenile call. - Juvenile calls were uttered by juveniles. These calls were phonetically rendered as "chreee . . . . chreee . . . .". The minimum, maximum and range of frequencies were $3.73 \pm$ $0.09,7.37 \pm 0.03$ and $3.64 \pm 0.09 \mathrm{kHz}$ respectively. The duration was $0.29 \pm 0.01 \mathrm{~s}$ with an interval of $1.43 \pm 0.11 \mathrm{~s}$ between calls. The average rate of juvenile call was $39.48 \pm 1.88$ calls per minute (Table 1).

Begging call. - Finally, the begging call was observed to be uttered by nestlings and fledglings. The inspection of spectrograms revealed that there are three element types of begging calls uttered by nestlings. The type I begging calls were rendered as "che ... . che .... che ...." which uttered at the early phase of nestling stage (Day 2 until Day 5). The minimum, maximum and range of frequencies were $2.90 \pm 0.04,5.01 \pm 0.10$ and $2.11 \pm 0.08 \mathrm{kHz}$, respectively. The call duration was $0.14 \pm 0.01 \mathrm{~s}$ with an interval of $0.71 \pm 0.05 \mathrm{~s}$ between calls. The average rate of type I begging call was $83.96 \pm 4.22$ calls per minute (Table 1). The type II begging calls were rendered as "chree .... chree ... . chree ... ." which were uttered during mid-phase of nestling stage (Day 6 until Day 12). The minimum, maximum and range of frequencies were $4.64 \pm$ $0.12,6.44 \pm 0.16$ and $1.81 \pm 0.13 \mathrm{kHz}$, respectively. The call duration was $0.26 \pm 0.02 \mathrm{~s}$ with an interval of $0.91 \pm 0.23 \mathrm{~s}$ between calls. The average rate of this type II call was $72.60 \pm 4.71$ calls per minute (Table 1). Nestlings were observed to utter the type III begging calls during the last stage of nestling stage (Day 13 until fledge). The characteristics of 


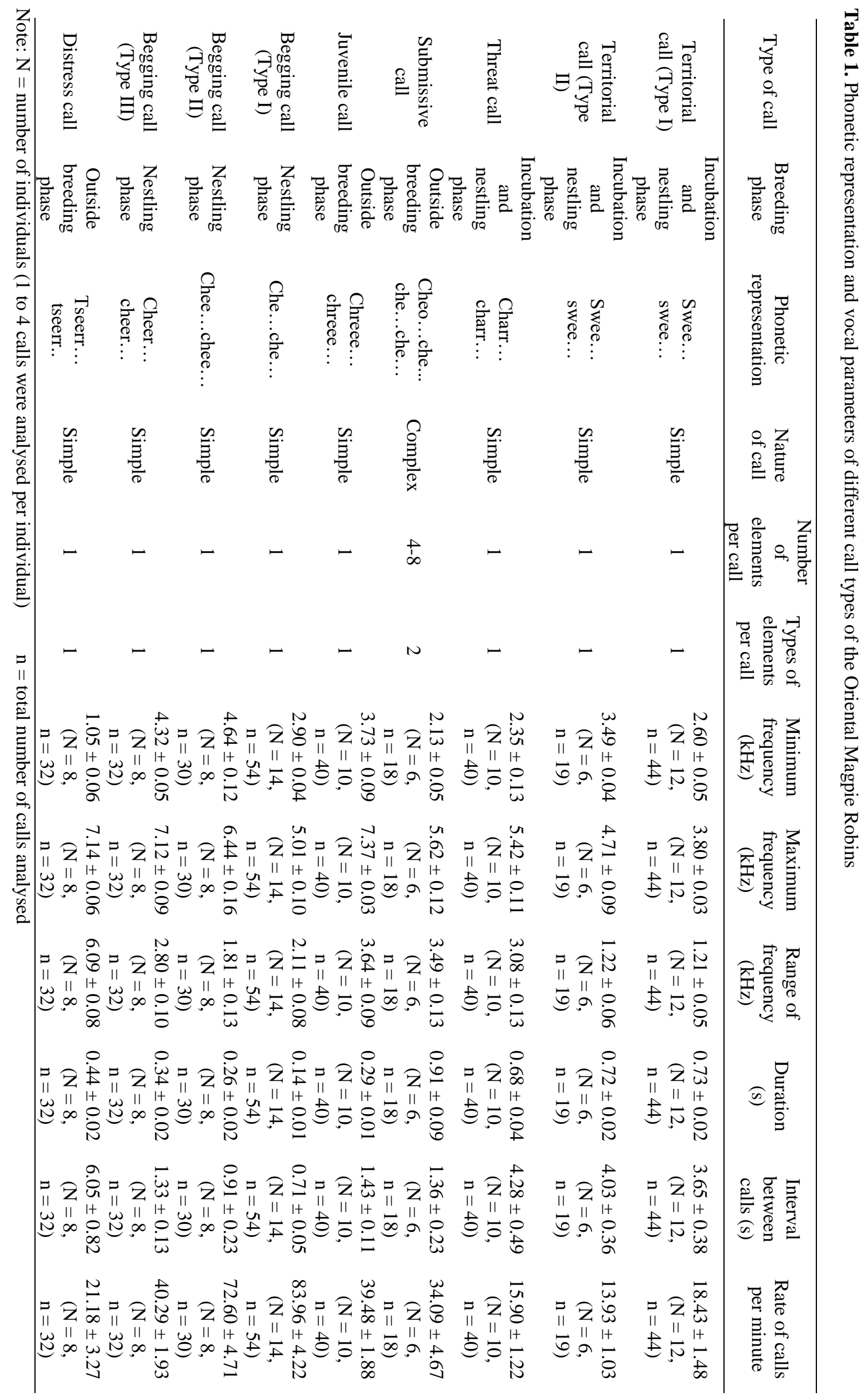


type III calls were almost identical to the type II.

However, the type III begging call was phonetically harsher and sharper than the type II. The minimum, maximum and range of frequencies were $4.32 \pm 0.05,7.12 \pm 0.09$ and $2.80 \pm 0.10 \mathrm{kHz}$, respectively. The call duration was $0.34 \pm 0.02 \mathrm{~s}$ with an interval of $1.33 \pm 0.13 \mathrm{~s}$ between calls. The average rate of type III begging call was $40.29 \pm$ 1.93 calls per minute (Table 1 ).
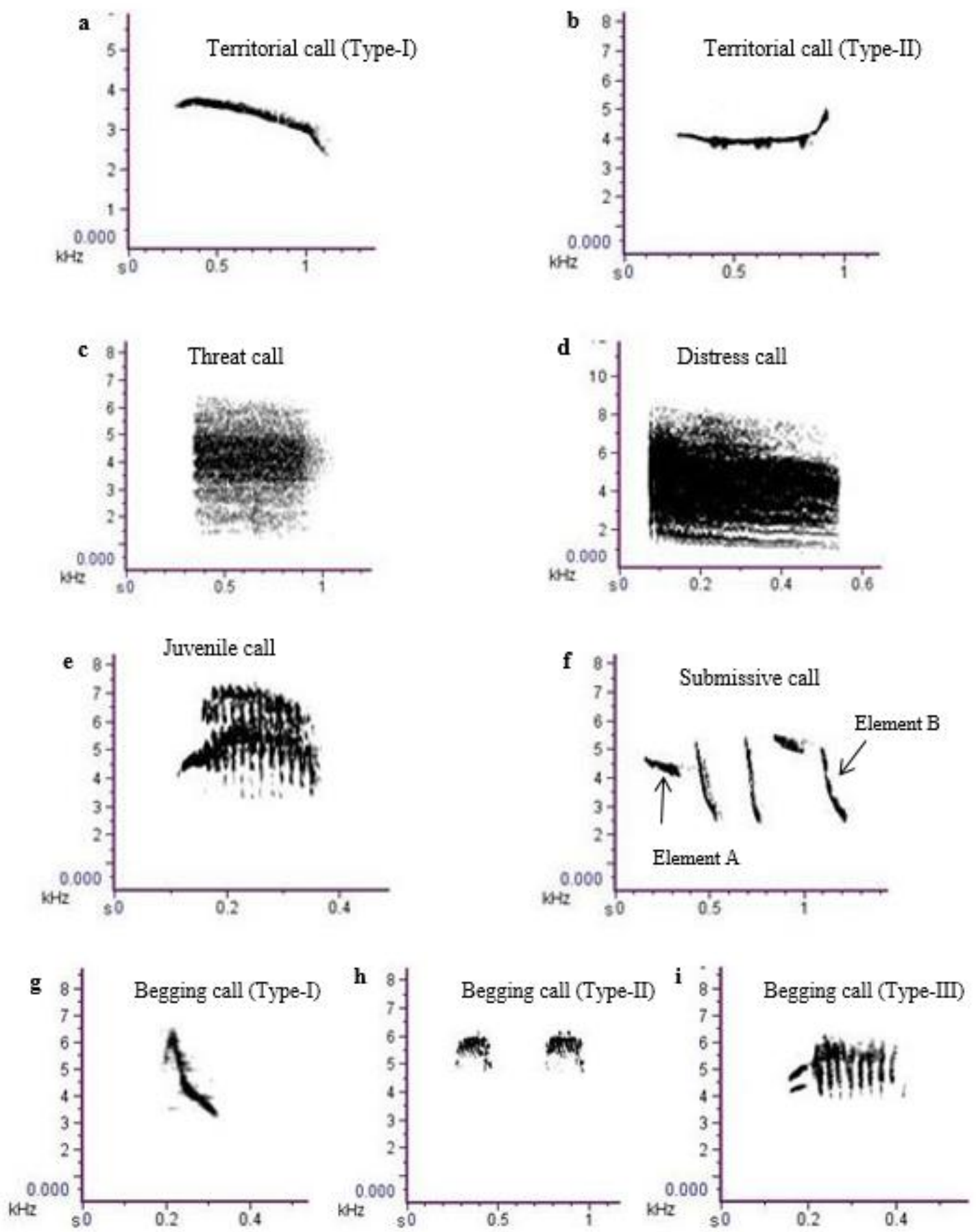

Figure 1. Spectrograms showing different types of call of the Oriental Magpie Robin where (a) and (b) are two types of territorial call, (c) threat call, (d) distress call, (e) juvenile call, (f) submissive call, (g), (h) and (i) are three types of begging call 


\section{DISCUSSION}

Based on field observation, the oriental magpierobins marked their territorial boundaries with territorial calls throughout breeding season. This call type was often pointed to conspecific nearby territory holders probably to negotiate their territorial boundaries with neighbouring males (Sethi et al., 2012). The territorial call is prevalence in many song bird species and has been reported to occur during breeding season in many tropical species including Indian Chat (Cercomela fusca) and Pied Bush Chat (Saxicola caprata) (Sethi \& Bhatt, 2008; Sethi et al., 2012). However, in contrast to this study, Bhatt et al. (2000) and Kumar \& Bhatt (2001) reported that territorial calls by male Oriental Magpie Robin in India were mostly produced outside breeding season ranged from September to February. The production of territorial calls in this season is crucial in securing their territories and to defend food resources.

In many species, threat calls are responsible in deterring intruders or any potential disturbances that exist within their breeding territory (Kumar \& Bhatt, 2001; Kumar, 2004; Sethi et al., 2012). Results have defined threat calls as a narrow range of frequency while having an abrupt onset and termination, and these characteristics resemble mobbing calls in many species (Johnson et al., 2003). These features enable the intruder to be located and may facilitate the recruitment of other conspecific in harassing predators (Marler \& Hamilton, 1966). In the case of the Oriental Magpie Robin, when a female started to produce threat calls once potential threats (i.e. non-conspecific birds, cats and humans) exist in the territory, its male partner which probably was away from their nesting site would return to the nesting site, and immediately joined the female in delivering the threat calls. Both sexes were observed to utter threat call while displaying a threat posture similar to that reported by Kumar and Bhatt (2002). The use of threat or alarm calls to alert breeding partners of nest disturbances has also been reported in Barn Swallow (Hirundo rustica), Dusky-capped Flycatcher (Myiarchus tuberculifer) and Pied Bush Chat (Saxicola caprata) (Ficken \& Popp, 1996; Payakkhabut, 2012; Sethi et al., 2012).

The association between territorial and threat calls were strongly exhibited by Magpie robins throughout this study. Both call types were sporadically uttered alternately within an episode of calling in response to disturbances mentioned earlier. It can be postulated that a series of this alternation of calling was presumably to advertise the boundary of territory while at the same time to harass the intruders. Similar occurrence also has been reported in Pied Bush Chat (Sethi et al., 2012).

Kumar and Bhatt (2001) revealed that these submissive calls were uttered by rivals or conspecifics usually females, when they were chased by males after been caught intruding the males' territories during non-breeding season. In this study, submissive calls were suddenly uttered while the birds were on perches before flying to another perches. No confrontations between males and rival or conspecifics were observed. Probably, the confrontations between them were overlooked before the submissive calls were heard. Surveys on the past literatures revealed that the occurrences of submissive calls were uncommon in many avian species (Kumar \& Bhatt, 2001). However, submissive postures have been reported in some birds (Marler \& Hamilton, 1966).

Distress calls in the Magpie robins can be described as loud, harsh, having an abrupt onset and termination and possesses slightly wider and higher range of frequency in comparison to threat call. Having similar characteristics just like threat calls is probably to enhance and pronounce their conspicuousness in order to get help by conspecifics during stress situation (Kumar \& Bhatt, 2001; Kumar, 2004; Marler \& Slabbekoorn, 2004; Sethi et al., 2012). The responses of birds upon stress situation varied across species. Some species may fight and struggle to escape while some may remain silent and motionless (Perrone, 1980; Sethi et al., 2012). In the case of Magpie robin, adults were observed to struggle and fight while at the same time uttering distress calls. However, Kumar and Bhatt (2001) reported this call been uttered mostly by fledglings while rarely uttered by adults.

In many species, the interaction between young and parents (parent-young interaction) can be characterised by the production of begging calls or contact calls by nestlings and provisioning calls by parents (Bengtsson \& Rydén, 1981; Clemmons, 1995). In this study, field observations have recorded regarding the utterances of provisioning calls which is phonetically rendered as "chirrrp..." by both parents with food in their bills while 
making perches in the proximity to the cavity before delivering food to their young. It can be postulated that the utterances of provisioning calls were simply just to alert the young regarding the arrival of parents with food so that the nestlings were prepared to accept the food. However, the utterances of provisioning calls were occasional and did not occur in every provisioning trips made. Kumar and Bhatt (2001) reported that the provisioning calls of Magpie robin parents in India were absent. In the case of nestlings, begging calls were uttered mainly to beg for foods from parents. Begging calls stimulate parental provisioning activities which is crucial for the development of young (Sethi \& Bhatt, 2007). Field observations revealed that the characteristics of begging calls phonetically and physically changed as well as their behaviour as the nestlings grow older. Nestlings produced begging calls almost the times in any situations during the early phase of nestling stage. As they grow older, nestlings that have already developed flight feathers did not make any sounds even when potential disturbances approaching nest. The nestlings only uttered begging calls when parents had arrived in the nest.

Juveniles of Magpie robin were observed to utter juvenile call in their habitats. Throughout the study period, juveniles were seen making perches somewhere in their habitat while uttering this call without displaying any engagement of defending or advertising any breeding territory. According to Kumar and Bhatt (2001), juvenile call has been associated with the learning process of juveniles to vocalise.

\section{CONCLUSION}

The Oriental Magpie-Robin is an ideal model to study acoustic communication in Bornean birds as it is a commonly available species. This bird utters territorial calls, threat calls, submissive calls, juvenile calls, begging calls and distress calls during breeding and non-breeding seasons. Parents were observed to occasionally utter provisioning calls during nestling stage. The physical characteristic of call types in this species has no differences between males and females. To add, the Oriental Magpie-Robin is also a suitable model to investigate a wide variety of questions associated to evolution, behavioural ecology and sociobiology, for example acoustic adaptation to various habitats.

\section{ACKNOWLEDGEMENTS}

We would like to thank the Faculty of Resource Science and Technology, Universiti Malaysia Sarawak for their help in providing the recording equipment. We also would like to thank the Cornell Ornithology Lab of Cornell University for their kindness in granting us a permanent academic licence enabling us to have a full access of Raven Pro software. This research was funded by Special Grant Scheme F07/SpGS/1563/2017.

\section{REFERENCES}

Ali, S. \& Ripley, S.D. (2001). Handbook of the birds of India and Pakistan. New Delhi: Oxford University Press.

Bengtsson, H. \& Rydén, O. (1981). Development of parent-young interaction in asynchronously hatched broods of altricial birds. Ethology, 56(3): 255-272.

Bhatt, D., Kumar, A., Singh, Y. \& Payne, R.B. (2000). Territorial songs and calls of the Oriental Magpie Robin (Copsychus saularis). Current Science, 78: 722-728.

Bhattacharya, H., Cirillo, J., Subba, B.R. \& Todt, D. (2007). Song performance rules in the Oriental Magpie Robin (Copsychus saularis). Our Nature, 5(1): 1-13.

Bradbury, J.W. \& Vehrencamp, S.L. (2011). Principles of animal communication. Second edition. Sunderland, MA: Sinauer Associates Inc.

Byers, B.E. (1996). Geographic variation of song from within and among chestnut-sided warbler populations. The Auk, 113(2): 288-299.

Carey, C. \& Dawson, W.R. (1999) A search for environmental cues used by birds in survival of cold winters. In: Nolan V., Ketterson E.D. \& Thompson, C.F. (Eds.) Current ornithology. Vol 15. Springer, Boston, MA.

Catchpole, C.K. \& Slater, P.J.B. (2008). Bird song: biological themes and variations. Cambridge: Cambridge University Press.

Clemmons, J.R. (1995). Vocalizations and other stimuli that elicit gaping in nestling Black Capped Chickadees (Parus atricapillus). The Auk, 112(3): 603-612.

Ficken, M.S. \& Popp, J. (1996). A comparative analysis of passerine mobbing calls. The Auk, 113(2): 370380 . 
Johnson, F.R., McNaughton, E.J., Shelley, C.D. \& Blumstein, D.T. (2003). Mechanisms of heterospecific recognition in avian mobbing calls. Australian Journal of Zoology, 51(6): 577-585.

Kumar, A. \& Bhatt, D. (2001). Characteristics and significance of calls in the Oriental Magpie Robin. Current Science, 80(1): 77-82.

Kumar, A. \& Bhatt, D. (2002). Characteristics and significance of song in female oriental magpie robin (Copsychus saularis). Journal of Bombay Natural History Society, 99(1): 54-58.

Kumar, A. (2003). Acoustic communication in birds. Resonance, 8(6): 44-55.

Kumar, A. (2004). Acoustic communication in the redvented bulbul (Pycnonotus cafer). Annals of the Brazzilian Academy of Sciences, 76(2): 350-358.

Lekagul, B. \& Round, P.D. (1991). A guide to the birds of Thailand. Sahakarnbhaet: Bangkok.

Mann, C. F. (2008). The birds of Borneo. Peterborough: British Ornithologists Union.

Marler, P. \& Hamilton, W.J. (1966). Mechanisms of animal behaviour. New York: John Wiley and Sons. Inc.

Marler, P. \& Slabbekoorn, H. (2004). Nature's music: The science of birdsong. New York: Academic Press.

Payakkhabut, S. (2012). Vocal communication in sooty- headed bulbul (Pycnonotus aurigaster). International Scholarly and Scientific Research and Innovation, 6(4): 140-145.

Perrone, M. (1980). Factors affecting the incidence of distress calls in passerines. The Wilson Bulletin, 92(3): 404-408.

Sethi, V.K. \& Bhatt, D. (2007). Provisioning of young by the oriental magpie robin (Copsychus saularis). The Wilson Journal of Ornithology, 119(3): 356370.

Sethi, V.K. \& Bhatt, D. (2008). Call repertoire of an endemic avian species, the Indian chat (Cercomela fusca). Current Science, 94(9): 1173-1179.

Sethi, V.K. Bhatt, D. \& Kumar, A. (2012). Characteristics and behavioural correlates of call types in a tropical bird, the pied bush chat (Saxicola caprata). Pakistan Journal of Zoology, 44(5): 12311238.

Vincze, O., Vagasi, C.I., Pap, P.L., Osvath G. \& Moller, A.P. (2015). Brain regions associated with visual cues are important for bird migration. Biology Letters, 11: 20150678.

Voon, A.M.F., Nasradhi, K.N.A.K., Rahman, M.A. \& Mohd-Azlan, J. (2014). Bird diversity, density and foraging activities in a university campus landscape in Sarawak. Borneo Journal of Resource Science and Technology, 4(2): 9-20.

Wells, D.R. (2007). The birds of the Thai-Malay Peninsula. Vol. 2: Passerines. London: Christopher Helm. 